NBER WORKING PAPER SERIES

\title{
FINDERS KEEPERS: \\ FORFEITURE LAWS, POLICING INCENTIVES, AND LOCAL BUDGETS
}

\author{
Katherine Baicker \\ Mireille Jacobson \\ Working Paper 10484 \\ http://www.nber.org/papers/w10484
NATIONAL BUREAU OF ECONOMIC RESEARCH
1050 Massachusetts Avenue
Cambridge, MA 02138 \\ May 2004
}

The authors thank Amitabh Chandra, Tom Chang, Julie Cullen, Alan Durell, Erzo Luttmer, Sendhil Mullainathan, David Rasmussen, Bruce Sacerdote, Antoinette Schoar, and Douglas Staiger for helpful discussions. We are especially grateful to Nancy Becker Bennett, Nancy Kniskern, Letty Kress, Craig Rockenstein, Karen Ziegler and other officials in Arizona, California, Florida, Michigan, New York, and Pennsylvania for making data available. We also thank Justin McCrary for graciously making all of his data on mayoral election cycles available and Bruce Benson, David Mast, and David Rasmussen for sharing their data on state forfeiture sharing rules. Baicker gratefully acknowledges research support by the Rockefeller Center at Dartmouth. All remaining mistakes are our own. The views expressed herein are those of the author(s) and not necessarily those of the National Bureau of Economic Research.

(C2004 by Katherine Baicker and Mireille Jacobson. All rights reserved. Short sections of text, not to exceed two paragraphs, may be quoted without explicit permission provided that full credit, including $\odot$ notice, is given to the source. 
Finders Keepers: Forfeiture Laws, Policing Incentives, and Local Budgets

Katherine Baicker and Mireille Jacobson

NBER Working Paper No. 10484

May 2004

JEL No. H0, H7, K0, K4

\section{ABSTRACT}

In order to encourage anti-drug policing, both the federal government and many state governments have enacted laws that allow police agencies to keep a substantial fraction of assets that they seize in drug arrests. By adjusting their own allocations to police budgets, however, county governments can effectively undermine these incentives, capturing the additional resources for other uses. We use a rich new data set on police seizures and county spending to explore the reactions of both local governments and police to the complex incentives generated by these laws. We find that local governments do indeed offset the seizures that police make by reducing their other allocations to policing, undermining the statutory incentive created by the laws. They are more likely to do so in times of fiscal distress. Police, in turn, respond to the real net incentives for seizures, once local offsets are taken into account, not simply the incentives set out in statute. When de facto policies allow police to keep the assets they seize, they seize more. These findings have strong implications for the effectiveness of using financial incentives to solve agency problems in the provision of public goods in a federal system: agents respond to incentives, but so do intervening governments, and the effectiveness of federal and state laws in influencing agents' behavior is limited by the ability of local governments to divert funds to other uses.

Katherine Baicker

Department of Economics

Dartmouth College

6016 Roskefeller Hall

Hanover, NH 03755

and NBER

kbaicker@dartmouth.edu

Mireille Jacobson

Planning, Policy, and Design

School of Social Ecology

University of California, Irvine

Irvine, CA 92697-7075 


\section{INTRODUCTION}

In an effort to induce police to do more anti-drug policing, both the federal government and many state governments introduced laws in the 1980s that allow police agencies to keep a substantial fraction of assets that they seize in drug arrests. This practice, known as drug-related civil asset forfeiture, has been a source of considerable controversy, as the legal hurdles for forfeiture are lower than for criminal conviction and those subject to seizures can find it difficult to recover their property, even when they are found innocent of related criminal charges. ${ }^{1}$ Many claim (and our data confirm) that for some localities forfeitures have become a major revenue source for local police and prosecutors. Thus, law enforcement agencies may be motivated not only by the desire to deter the crime, but also by the added incentive of potential proceeds from anti-crime policing.

Agency problems in the provision of public goods (and the strategies for solving them) are certainly not unique to policing. Local school boards may try to undo the effects of statelevel school finance reforms, while teachers may not adopt the curriculum dictated by the school board. ${ }^{2}$ Welfare caseworkers may not strictly enforce the eligibility criteria included in welfare reform. There are a number of different strategies for solving these agency problems. In some circumstances, perfect contracts or laws can be written. When perfect contracts or laws are not possible (such as when the agents' actions are unobservable or multi-year commitments cannot be made), however, incentives may be used to induce the desired behavior. This strategy has been more commonly used in the private sector, but monetary incentives are used increasingly in

\footnotetext{
${ }^{1}$ Although this is a common criticism of forfeiture laws (See Benson. Rasmussen, and Sollars (1995); Blumenson and Nilsen (1998); Mast, Benson, and Rasmussen (2000); and Worrall (2001)), this behavior is consistent with the laws' intent. Law enforcement officials maintain that asset forfeiture is a powerful tool that allows them to "disrupt the 'working capital' of criminal organizations" (Stellwagen 1985) and "take the profit out of crime" (Cassella 1997), thereby deterring future drug crimes as well as punishing current criminals.

${ }^{2}$ See Baicker and Gordon (2004).
} 
the provision of public goods - as in the sharing provisions of asset forfeiture laws.

The reactions of local governments to these laws highlight a fundamental problem in the use of incentives to solve agency problems in the provision of public goods in a federal system. When several levels of government are involved in the provision of public goods, they may have competing goals and constraints. In this case, while the states may have introduced incentives to induce anti-drug policing, county governments also have jurisdiction over police policy and police budgets. Counties have the ability to adjust their allocations to police, in effect undoing the incentives created by the state.

This paper explores the effect of the incentives created by asset forfeiture laws on the behavior of both local governments and agents. We analyze the effect of asset forfeiture laws on police behavior, local budgets, and the relationship between the two. The relationship between police seizures and local allocations to the police budget is more complex than a naïve interpretation of the statutes would suggest. While the laws were designed to increase anti-drug policing by creating monetary rewards for seizures, some states' laws explicitly acknowledge that local governments could (but should not!) reduce their own allocations to police in response. ${ }^{3}$ Moreover, local governments may be more likely to do this in some circumstances (such as when under fiscal distress) than in others. Police may respond to the de jure incentives created by the laws, or to the de facto incentives in place after county off-setting behavior is taken into account.

We use new and original data on drug-related seizures combined with detailed data on county budgets to answer two sets of questions. First, do asset forfeiture laws really increase law enforcement budgets, or do local governments act to undo those incentives with offsetting 
changes in police budgets? Are they more likely to do so when they face tighter budget constraints? Second, how do police change their seizure behavior in response to seizure laws? Do they respond to the gross or the net incentives created by the laws?

We find that local governments do indeed partially offset police seizures by reducing their own allocations to those police budgets the following year. Total police resources thus do not increase by as much as a simple estimate of their gross seizures would suggest. We find that counties in some states and in some circumstances offset a much greater fraction of police seizures than others. For example, the presence of a budget deficit causes counties to reduce their allocations in response to seizures much more - and to allocate those funds toward spending on programs like public welfare. To disentangle the effect of county offsetting from police reactions to changes in their budgets, we use data on the timing of mayoral elections, which, as suggested by Levitt (1997) and McCrary (2002), is systematically associated with an increase in resource allocations to police. We find that police responses to these (anticipated) budget windfalls are relatively small compared to our estimates of county budgetary offsets. Our estimates of large county budget offsets in response to seizures are thus robust to the potential endogeneity of police seizures.

We also find that the net incentives created by forfeiture policies influence the behavior of the targeted government agents. To the extent that law enforcement agencies do get to keep assets they seize, they respond by changing their pattern of policing and increasing seizures. Police devote substantially more of their effort to anti-drug policing when their net revenues from the activity are higher. These findings are consistent with previous studies by Benson, Rasmussen, and Sollars (1995) and by Mast, Benson, and Rasmussen (2000), which suggest that

\footnotetext{
${ }^{3}$ In fact, while many state laws such as Michigan's include provisions explicitly stating that proceeds from asset forfeiture are not meant to supplant funds normally provided to police by counties, these provisions are clearly
} 
federal and state seizure laws change policing behavior. Our analysis refines these estimates by distinguishing between de jure statutory sharing rules and the de facto net proceeds that police keep (after other government offsets) on the intensity of anti-drug policing, yielding much sharper estimates and a more complete picture of responses to complex incentives.

Together, these findings have strong implications for the effectiveness of using financial incentives to solve agency problems in the provision of public goods in a federal system. Police respond to incentives, but so do intervening governments. The effectiveness (and costliness) of federal and state laws in influencing agents' behavior is limited by the ability of local governments to divert funds to other uses.

\section{BACKGROUND ON FORFEITURE}

Private assets can be seized through both state and federal asset forfeiture laws. ${ }^{4}$ Understanding the relationship between these laws clarifies the net incentives faced by police, and thus their effect on both police budgets and policing activity.

Federal drug-related civil forfeiture law dates back to the Comprehensive Drug Abuse Prevention and Control Act of 1970. Since then, the authority of law enforcement agencies to seize assets has expanded greatly, from property used directly in the commission of a drug crime to that equal in value to "forfeitable assets that are no longer available" (Blumenson and Nilsen 1998, p. 45). In 1984, with the passage of the Comprehensive Crime Control Act, the federal government established an "Equitable Sharing" provision, whereby state and local agencies could request that the Department of Justice "adopt" and then return or share in a drug-related

\footnotetext{
unenforceable.

${ }^{4}$ Under federal law, assets can be seized in three ways: (1) administratively, meaning they are uncontested and no formal proceeding is required; (2) in a civil proceeding, meaning the property is contested and the government has
} 
asset seizure. The explicit motivation for this provision was to provide law enforcement at all levels with an incentive to pursue drug crimes.

DOJ's "success" in seizing assets in the early 1980s and its introduction of the equitable sharing program brought asset forfeiture policies to the attention of state governments. Many states responded by passing their own civil forfeiture laws or by simply tapping in to existing laws on the books. ${ }^{5}$ State forfeiture laws vary widely, however, in the fraction of seizures returned to the local agency, the way different types of property are treated, and the restrictions on use of funds. Some states return the bulk of funds to the seizing agency, while others contribute them to a general law enforcement fund, earmark them for specific uses, or pool them with general revenues. A few states have specific constitutional provisions requiring seized assets be devoted to education (e.g. Indiana and Missouri). Several others have recently passed reform measures further limiting the fraction of seizures that police can keep (e.g. Nevada) or outlawing forfeiture without a criminal conviction (e.g. Oregon). ${ }^{6}$ These restrictions are in part a response to reports of forfeiture-related abuses, which abound in both the popular press (e.g. Dillon 2000) and the academic literature (Blumenson and Nilsen 1998). ${ }^{7}$

Despite the specific sharing provisions laid out in statute, both federal and state agencies can exercise significant discretion in determining sharing. Local agencies themselves can

filed a civil complaint against the seized property; or (3) in a criminal proceeding, meaning a forfeiture count is included in the indictment of a criminal case.

${ }^{5}$ See Blumenson and Nilsen 1998 for a thorough overview of state laws.

${ }^{6}$ Nevada's law, which took effect in October 2001, requires that 70 percent of an agency's proceeds above $\$ 100,000$ be turned over to its county school district. The Oregon law, passed by referendum in November 2000, prohibits the forfeiture of property without a criminal conviction. Utah, Arkansas, and Missouri have also adopted reforms. See Blumenson and Nielsen (2001) and Di Eduardo (2001) for discussion of some of these reforms.

${ }^{7}$ The Civil Asset Forfeiture Reform Act (CAFRA) of 2000 further reigns in law enforcement's ability to seize real property under federal law by, among other things, shifting the burden of proof from property owners to the government and, barring exigent circumstance, requiring an order of forfeiture for the seizure of real property. It leaves intact, however, procedures for the seizure of cash, financial instruments, and conveyances (Short 2002). It also does nothing to alter the most controversial aspect of civil asset forfeiture laws: by requiring only proof by a "preponderance of evidence," a defendant's cash and property can be forfeited even if he is acquitted of criminal drug charges, which must meet the far tougher standard of proof "beyond a reasonable doubt." 
typically choose whether to process a seizure through state authority or to have it adopted by the DOJ. At first glance, one would assume that the agency would choose the route with the more generous statutory sharing provision (which varies across states and time, according to the provisions and timing of state laws). Conversations with specific state agencies (detailed below), however, suggest that the DOJ often makes "deals" with local agencies to adopt seizures, and that state agencies with discretion over the disposition of seized assets are also often willing to negotiate with local agencies.

What is clear, however, is that local law enforcement agencies have the opportunity to increase their budgets through drug-related civil forfeitures. Indeed, the federal government once touted such "benefits" of forfeiture (see Stellwagen and Wylie 1985) and opinion data suggest law enforcement understood the message. Worrall (2001) conducted a survey to determine local agencies' perceptions of the role of asset forfeiture in their budgets. He finds that 30 to 45 percent of law enforcement executives agree that "civil forfeiture is necessary as a budgetary supplement." This study addresses the budgetary implications of forfeiture policies more quantitatively, by examining the actual relationship between seizures and local law enforcement budgets.

Several previous studies have examined the effect of seizure laws on local law enforcement behavior (with the prevailing claim being that local police respond to incentives by seizing more), but most of these studies do not adequately control for policy endogeneity or draw inferences about the broader budgetary implications of forfeiture policies. Benson, Rasmussen, and Sollars (1995) find a positive correlation between police seizures and police expenditures in a cross-section of some Florida agencies, but the causal connection is not clear. Mast, Benson and Rasmussen (2000) find a positive correlation between the statutory sharing in forfeiture laws 
and drug arrests as a fraction of total arrests in large cities. ${ }^{8}$ They have no data on the magnitude of seizures, examining instead state-year level variation in the fraction of seized assets police retain by statute. In this study, we use data on actual seizures to investigate the effect of these laws and net sharing on police behavior. We next present a conceptual framework and empirical strategy for understanding how state and federal forfeiture policies might affect both the budgetary decisions of county governments and the law enforcement activity of local police.

\section{CONCEPTUAL FRAMEWORK AND EMPIRICAL STRATEGY}

The choices faced by states, counties, and police agencies can be thought of as a standard principal-agent problem in a repeated game setting. Assuming state laws are given exogenously and policing effort is perfectly observed, then in each period the police must choose how much (costly) anti-drug policing effort to exert and the county has to choose how much of the seized funds to leave with the police, and how much to appropriate for county budgets through reduced allocations to police. ${ }^{9}$ We use a simplified approach that reduces both police and county preferences to a function of available resources (inputs), rather than outcomes from increased resources (lower crime or better schools). In other words, the county makes expenditure choices and the police make enforcement decisions that increase their own budgets. Legislators and police may be motivated to do this in part because, as individual agents, they can benefit from higher salaries or perks such as nicer offices or patrol cars (see Gordon and Wilson 1999).

The county is thus maximizing:

$$
U_{c}\left(X_{p}, X_{o}\right) \quad \text { s.t. } Y+T S \geq X_{p}+X_{o}
$$

\footnotetext{
${ }^{8}$ They also control for drug use in a sub-sample of 24 cities. Oddly, this variable has no significant effect on arrests. ${ }^{9}$ As noted below, county allocations to police are sufficiently large that they could offset the full amount of police seizures through reductions if they choose.
} 
where $\mathrm{X}_{\mathrm{p}}$ is spending on police and $\mathrm{X}_{\mathrm{o}}$ is spending on other goods, $\mathrm{Y}$ is (exogenously given) revenue, $\mathrm{T}$ is the statutory tax rate on police seizures, and $\mathrm{S}$ is the amount the police seize. Similarly, the police are maximizing:

$$
U_{p}\left(X_{p}+(1-T) S, S\right)
$$

where the arguments are the total size of the police budget (more is better), but also seizure effort (which they dislike). ${ }^{10}$

In each period, the police first choose an effort level that produces a seizure amount (which might be determined entirely by effort, or might be the product of effort and noise), and the county then chooses how much money to allocate to policing. If this were a one-period game, the county would treat its share of the seizure proceeds (TS) as unconstrained income, and would allocate it accordingly (with presumably only a small share to policing). ${ }^{11}$ In that case, however, police would have no incentive to make seizures. Because this is a repeated interaction and the county cares about future income from seizures, the county is motivated to leave incentives in place for police to seize. This implies that changes in county allocations to police will not completely offset the seizures made by police $\left((1-T)+\frac{\partial X_{P}}{\partial S}>0\right)$, while seizures will be a positive function of the net return to police $\left(\frac{\partial S}{\partial\left((1-T)+\frac{\partial X_{P}}{\partial S}\right)}>0\right)$. Furthermore, if the county

\footnotetext{
${ }^{10}$ The government's problem of choosing an implicit tax rate on seizures to maximize revenues is analogous to the problem of labor supply taxation, where labor supply (like seizures) declines with the tax rate.

${ }^{11}$ If the county is making utility-maximizing allocations to the police, when new funds are generated by seizures, the county would presumably choose to allocate some small portion of them to policing, just as it chooses to allocate some of its income to policing. Given that the fraction of the income of county residents allocated to policing is small, this unconstrained fraction would likely be very small as well.
} 
has convex preferences for spending, shocks to other income (Y) may affect its offsetting behavior (particularly if the police can observe these shocks as well and have negotiated based on the expected distribution of these shocks). If counties value income more highly in times of fiscal distress, then they would offset more of police seizures in those times $\left(\frac{\partial^{2} X_{p}}{\partial S \partial Y}<0\right)$. We estimate empirically these relationships between statutory sharing, county offsets, police effort, and seizures.

We first examine the net effect of seizures made by local law enforcement agencies on their budgets $\left(\frac{\partial X_{P}}{\partial S}\right)$. Although many state forfeiture laws were written so as to provide a "windfall" to law enforcement (Stellwagen and Wylie 1985), this intent can be effectively undone through budget offsets. In other words, parent (county) government can reduce its own allocations, eliminating any increase in police resources through seizures. We thus estimate:

$$
\text { Police Budget }_{\text {ist }}=\alpha_{i s}+\alpha_{t}+\beta_{1} \text { Seizures }_{\text {is }, t-1}+X_{\text {ist }} \Gamma+\varepsilon_{\text {ist }}
$$

where $i$ indexes counties, $s$ indexes states, and $t$ indexes time. We include county and year fixed effects and covariates such as crime rates, unemployment, and the size of county government. Police budgets and seizures are expressed in real per capita terms. We weight regressions by the population in each county, and cluster standard errors at the state level. ${ }^{12}$ We used lagged seizures in this OLS specification as a first attempt to capture the causal effect of seizures on budgets. ${ }^{13}$

It is important to note that the seizures police make are not included in the budgets they receive from their parent (county) governments. $\beta_{1}$ thus captures the degree to which counties

\footnotetext{
${ }^{12}$ The survey results in Worrall (2001) indicate that large police agencies, which typically correspond to police agencies in large jurisdictions, report greater reliance on and use of asset forfeiture.
} 
change police budgets in response to police seizures. We include analysis both of seizures made through state statutes and seizures made through the DOJ. We are also interested in the heterogeneity of offsetting behavior. To examine differential responses to local seizures, we include the interaction of seizures with local deficits $\left(\frac{\partial^{2} X_{P}}{\partial S \partial Y}\right)$ :

$$
\text { Police Budget }_{i s t}=\alpha_{i s}+\alpha_{t}+\beta_{1} \text { Seizures }_{i s, t-1}+\beta_{2} \text { Seizures }^{*} \text { Deficit }_{i s, t-1}+X_{i s t} \Gamma+\varepsilon_{i s t}
$$

To the extent that counties reduce their allocations to police, they have extra funds to spend on other programs or to reduce tax revenues. To explore the use of these funds, we also include other categories as alternate dependent variables.

There is clearly the possibility for causality to run the other direction: police may respond to changes in the budget allocated to them by the county. While the timing of these reactions helps give some insight into causal pathways, the persistence of both policing patterns and county budgets makes it difficult to rely on timing alone to determine causality in a simultaneous-equation framework. To better gauge the extent of reverse causality, we use an instrumental variables approach to estimate:

$$
\text { Seizures }_{\text {ist }}=\alpha_{i s}+\alpha_{t}+\beta_{1} \text { PoliceBudgets }_{i s, t-1}+X_{\text {ist }} \Gamma+\varepsilon_{\text {ist }}
$$

Our approach builds on the fact established by Levitt (1997) and further validated by McCrary (2002) that municipal police hiring varies across election cycles, increasing relative to the average in election years. The obvious corollary is that, relative to the average, police spending systematically increases in election years in a way that is unrelated to crime. We first demonstrate this occurrence. We then use variation in the timing of mayoral election cycles as

\footnotetext{
${ }^{13}$ Results controlling for lagged or contemporaneous arrests are virtually identical.
} 
our instrument for municipal spending on police to estimate the effect of budgetary changes on drug-related asset forfeiture. ${ }^{14}$ We can thus evaluate the extent to which local police vary their seizure and drug arrest activity as a means to supplement their budgets in response to a shortfall or reduce their effort in response to a windfall. This allows us to put a bound on the extent to which our previous estimates of county "offsetting" behavior may instead be capturing the reaction of police to anticipated budgetary changes. ${ }^{15}$

The second question we ask is whether or not police respond to the (net) incentives for seizures. The de jure incentive to seize is written into federal and state laws, and we see whether police seize more and focus more on anti-drug policing when the statutory sharing rule is higher. We analyze both the quantity of seizures and the number of arrests police make to capture relative effort exerted by police. We thus estimate: ${ }^{16}$

$$
\text { Policing Behavior }_{\text {ist }}=\alpha_{t}+\beta_{1} \text { Statutory Sharing }{ }_{\text {st }}+X_{\text {ist }} \Gamma+\varepsilon_{\text {ist }}
$$

Because localities may act to offset police seizures through reductions in their allocations to police, however, the de facto incentives faced by police may be much smaller. We next characterize states into those where counties do a lot of offsetting versus those where little offsetting occurs by including state-specific interactions with DOJ program seizures in equation (1). We consider DOJ as opposed to state seizures because we have this data for all states, and because all localities face the same statutory sharing percentage from seizures made through the

\footnotetext{
${ }^{14}$ Note we use the term shocks to mean changes that are uncorrelated with crime, rather than unanticipated by police.

${ }^{15}$ Somewhat more formally, the potential for reverse causality suggests a system of two simultaneous equations: Seizures $_{\text {ist }}=\beta_{i s}+\beta_{t}+\beta_{1}$ PoliceBudgets $_{i s, t-1}+X_{\text {ist }} \mathrm{B}+\varepsilon_{\text {ist }}$ PoliceBudgets $_{\text {ist }}=\gamma_{i s}+\gamma_{t}+\gamma_{1}$ Seizures $_{\text {is }, t-1}+\gamma_{2}$ Election $_{\text {it }}+X_{\text {ist }} \Gamma+\varepsilon_{\text {ist }}$

If, as previous literature suggests (and we show below), mayoral elections affect police budgets but not seizures directly, we can use the mayoral election cycle to separately identify $\beta_{1}$ and $\gamma_{1}$.
} 
federal program. We then use the state-specific estimates of DOJ offsetting behavior as a measure of how much localities in each state are likely to offset seizures through the DOJ program. We construct a state-level dummy variable based on the size of this coefficient - states with smaller than average coefficients (in absolute value) are classified as "low offsetters" and states with higher than average coefficients are classified as "high offsetters."

The net financial incentive for police to increase seizures and anti-drug policing should be a function of the de facto increase in their budget - which is a function of both statutory rates and offsetting behavior. We thus estimate:

Policing Behavior $_{\text {ist }}=\alpha_{t}+\beta_{1}$ Statutory Share $_{\text {st }}+\beta_{2}$ Statutory Share $_{\text {st }} *$ Low Offset $_{s}+X_{\text {ist }} \Gamma+\varepsilon_{\text {ist }}$

to see whether police respond to the de facto incentives they face.

\section{DATA}

We use data from several different sources to perform this analysis. One important and novel component is that we have collected information on the value of seizures made by police agencies through 5 individual state statutes. We also use publicly available data on forfeitures through the DOJ for all continental states, as well as local government spending, crime, and other covariates. These data, which are discussed below, are summarized in Table 1. Panel A gives summary statistics for the full sample and Panel B for the 5 states for which we have stateprogram seizure data.

\footnotetext{
${ }^{16}$ As described below, state sharing rules do not vary within states over the time period for which we have state seizure data, so we cannot include county fixed effects.
} 


\section{Forfeitures through State Programs}

Information on assets seized through state programs is not collected nationally, and different states have different reporting requirements and data availability. We have gathered data on assets seized by local law enforcement agencies in (parts of) the 1990s for California, Florida, Pennsylvania, Arizona, and New York. Details on the form and scope of these data are included in Appendix 1. We have aggregated these seizures to the county-year level. As shown in Table 1, in our sample of 5 states, police seize roughly one dollar per capita per year or about 1.4 percent of their annual police budget through state statutes. (The between-county standard deviation is about two-thirds as large as the within-county standard deviation.)

We follow the work of Mast, Benson and Rasmussen (2000) and Worrall (2001) in codifying the sharing rules in each state, supplemented by our discussions with state officials. Each state's statute defines the fraction of seizures that are to be returned to the seizing (police) agency. For example, in New York the statute dictates that 40 percent of net proceeds be returned to the police agency, while in California 65 percent is returned. The Pennsylvania statute suggests that all of the funds are to be allocated at the discretion of the District Attorneys and Attorneys General, but in practice many of these funds are returned to the police.

\section{Federal Department of Justice Forfeitures}

We also analyze the seizures that local agencies make through the DOJ. Pursuant to the Comprehensive Crime Control Act of 1984, state and local agencies can request federal adoption of asset seizures if (1) a federal agency was involved in the seizure or (2) the seizure was made pursuant to the commission of a federal crime that provides for seizure, as is the case with any drug offenses. After the seizure is "adopted" by the Department of Justice, the government can 
return up to 80 percent of the proceeds back to the seizing agency (before 1990, 90 percent could be returned). DOJ does, however, set minimums on the value of seizures in adoptive cases.

Data on seizures through the federal program are available annually from 1990 to 1998 at the judicial district level. Unfortunately, these judicial reporting districts are often much bigger than counties (or the agencies responsible for the seizure and in receipt of the revenues). We allocate these seizures to counties based on population. We explore the validity of this allocation using supplemental data on DOJ disbursements to individual local agencies, which are available from 1998 to $2001 .{ }^{17}$ A regression of the log of DOJ disbursements to counties on the log of population, year fixed effects, and the covariates discussed below yields a coefficient on the log of population of 1.06 (with a standard error of .04), suggesting that disbursements flow to counties roughly in proportion to their population.

In the full sample, police seize almost two dollars per capita through the federal statute. Thus, DOJ-processed seizures amount to about 4.3 percent of county allocations to police. In our 5-state sample, police seize over three and a half dollars per capita through this program or about 4.8 percent of their county allocation. As suggested by the similarity in the percent of allocations they represent across the two samples, per capita DOJ-processed seizures are likely higher in our 5-state sample because it is composed primarily of large industrialized states, with major metropolitan areas, established drug markets, and correspondingly large per capita police budgets. Moreover, although federally adopted seizures represent about 77 percent of the value of a county's total annual seizures in the 5-state sample, they are not necessarily the police's

\footnotetext{
${ }^{17}$ When agencies make seizures, the funds are deposited in a central account before being disbursed back to the local agencies based on the sharing rules. Disbursements (unlike deposits, which get reported in the year of seizure) occur with lags, depending on the timing of the disposition of the case. For this reason, and because of the limited data we have on disbursements through federal and state programs, we focus on seizures.
} 
preferred method of forfeiture. ${ }^{18}$ Rather, the DOJ will not adopt a seizure unless it is at least $\$ 5,000$ in cash, vehicles or monetary instruments or $\$ 20,000$ in real property. These DOJ minimums on the value of seizures in adoptive cases imply that seizures falling below federal thresholds must be processed through a state program. Moreover, typically major drug stings, the very cases that are likely to net significant assets, involve federal agencies, even when carried out by or with local police, and DOJ tries to exert its authority in the processing of such forfeitures.

\section{County Budget Data}

County and state revenues and expenditures are collected by the Census Bureau and are publicly available. Data on local budgets is available for all localities every 5 years from the Census of Government Finances, and for a sample (roughly half to two-thirds) annually from the Survey of Government Finances, through 2001. All analysis uses real per capita revenues or expenditures. Annual police budgets are roughly $\$ 45$ per capita for the full sample and $\$ 77$ per capita for the 5-state sample. As mentioned above, however, in both cases, DOJ-processed seizures are about 4 to 5 percent of police budgets. Together seizures processed through the federal and state statutes represent almost 7 percent of police budgets.

\section{Mayoral Elections}

Data on the year in which city-level mayoral elections are held come from McCrary (2002), following Levitt (1997). We match each of the 52 cities in the McCrary data set with the county in which they are located. We update the McCrary data for 2000 and 2001 using the

\footnotetext{
${ }^{18}$ Indeed, although some maintain that DOJ-sharing rules offer law enforcement a generous alternative to strict state sharing provisions (Blumenson and Nielsen 1998), conversations with several officials in such states (e.g. NJ) reveal that police typically prefer to process their seizures through the state.
} 
United States Conference of Mayors' Election Results Database: 1999-2003 (and verify using information posted on individual cities' web sites).

\section{Covariates}

Data on criminal activity and arrests is available annually at the county level through the federal Uniform Crime Reports. Total arrests per 100,000 residents and "index I" crime (murder, rape, robbery, aggravated assault, burglary, larceny, and motor vehicle theft) arrests per 100,000 are almost identical across the two samples. Drug arrests, however, represent about 9 percent of arrests reported in the overall sample and over 12 percent in the 5-state sub-sample. It is unclear how much of this represents greater drug enforcement versus greater drug activity in these states but either case should correspond to more forfeiture opportunities. We also use county-level data on unemployment from the Bureau of Labor Statistics.

\section{RESULTS}

Using this data we answer two questions. First, how much and under what circumstances do counties offset police seizures by reducing their allocations to police? Second, how do these incentives affect police behavior?

\section{County Offsets of Police Seizures}

The first issue we explore is the net effect of seizures on the rest of police budgets. If parent governments fully offset the financial "gains" from seizures, then seizures will have no effect on police resources. We estimate the effect of seizures through state programs (for our sample of 5 states) and through the DOJ program (for all states and the 5 state sub-sample) on county allocations to police budgets. All regressions control for index I crime arrests per capita, 
total county expenditures per capita, county unemployment rates, and county and year fixed effects. Table 2 reports these results with results for DOJ program seizures in Panel A and state program seizures in Panel B. Results in even columns also include state-specific time trends. ${ }^{19}$

Both Panels A and B suggest that increases in seizures within a county are associated with reductions in budgetary allocations to police the following year, although, as will be discussed below, the extent of offsetting depends on the type of seizure made. The consistency of this result is striking since conventional wisdom might have suggested a positive relationship between changes in police spending and seizures (if both are related to unmeasured increases in crime, changes in preferences, or increased resources for anti-drug policing).

Our results suggest that each dollar police seize through the DOJ program is offset dollarfor-dollar by reductions in county allocations to police, with coefficients of -1.55 for the full sample and -1.31 for the 5-state sub-sample (columns (1) and (3), respectively). Estimates including state-specific time trends, although significant at only the 11 and 13 percent levels, are also consistent with full budgetary offsetting in response to DOJ-processed seizures. According to statute, as much as 80 percent of these "federally adopted" seizures are returned to law enforcement, with the DOJ keeping the balance and state and county governments typically receiving nothing - but county governments use the budgetary authority at their disposal to capture much of the gains from seizures.

Seizures made through state programs, however, do not appear to be offset at the same rate. As shown in columns (3) and (4) of Panel B, each dollar of seizures made by police through the state program results in a reduction of an (insignificant) 25 to 40 cents in county allocations to police. (As discussed above, even in these 5 states the DOJ seizures are fully

\footnotetext{
${ }^{19}$ Results with county-specific time trends are quite consistent, but are computationally intensive and lack power because of the limited number of observations we have per county.
} 
offset.) This finding clears up some confusion about police usage of DOJ versus state program seizures. Many who have studied asset forfeiture maintain that DOJ-sharing rules offer law enforcement a generous alternative to strict state sharing provisions (Blumenson and Nielsen 1998). However, local police often prefer to process their seizures through the state, even when their state offers a less generous sharing rule than the federal government. These results provide some insight into why this is so: far from providing a bigger windfall, seizures processed through the DOJ are typically completely captured by the county government through reductions in allocations to police, while seizures through the state program are only partially offset.

Why would counties be less likely to offset the seizures made through the state program? First, state and county governments typically share in some fraction of state-processed seizures already (explored more below). Second, counties may in fact offset DOJ-seizures more than state-processed seizures as a way to "punish" local police for bypassing state and local authority and strengthen their incentive to seize through the state program. Finally, state laws may be enacted endogenously: that is, state seizure laws may be passed by states at a time when local governments intend to spend more on policing.

Unfortunately, we do not have an instrument for the enactment of state laws, but we can explore the circumstances under which these laws seem to bind most. One possibility is that when a locality faces fiscal distress, it co-opts more of the funds the police seize. To test this hypothesis, we include the size of a county's deficit (or surplus) as a regressor and the interaction between the deficit and seizures made by police in the county (either through state programs or the DOJ program), both lagged one year. ${ }^{20}$ As columns (5) to (8) of Panel A. show, the greater the fiscal stress on a county (as measured by the size of its deficit - real per capita expenditures minus real per capita revenues), the more it captures police seizures with offsetting reductions in 
its allocations to police. A $\$ 100$ per capita increase in the county deficit results in a 70 cent offset in DOJ program seizures and a 60 cent offset in state program seizures. These results are consistent across samples and are robust to the inclusion of state-specific time trends.

If counties usurp DOJ-processed seizures from police budgets, where do they spend the money? Table 3 explores the possible reallocation of police budgetary offsets by county governments. Counties appear to reallocate police budget offsets primarily to other criminal justice programs. ${ }^{21}$ In particular, a one dollar increase in seizures is associated with a roughly 80 to 95 cent increase in allocations to correctional and judicial budgets. In times of fiscal distress, however, offsets are redirected to increases in public welfare spending: a $\$ 100$ per capita increase in the county deficit results in a 90 cent offset in state program seizures but a corresponding increase in public welfare budgets. ${ }^{22}$ Spending on other budget categories, such as fire protection and health and hospitals (not shown here), does not respond to seizures, overall or in times of distress.

The results from Tables 2 and 3 suggest that the de jure share of seizures that police are supposed to receive by state and federal statute may not correspond to the de facto share that they actually receive when associated changes in their budget are taken into account. Seizures through the DOJ program seem to be entirely offset by localities, but seizures through state programs seem to be offset more in times of fiscal distress.

One potential problem with this specification is the dynamic reaction that police might

\footnotetext{
${ }^{20}$ A county deficit is its total spending less expenditures; thus the variable is positive in times of fiscal distress.

${ }^{21}$ This is consistent with Baicker's (2001) finding that the shock of financing a capital crime trial may be absorbed in part by decreases in police spending.

22 Interestingly county allocations to highways, like police, are reduced when seizures increase: a one dollar increase in seizures, either DOJ or state-processed, is associated with a roughly 50 cent reduction in county allocations to highways. In contrast to police offsets, seizure-related highway offsets do not increase in times of distress. Why would highway spending be reduced in response to seizures? One possibility is that highway budgets capture allocations to local highway patrol units, many of which make seizures of vehicles and the like when they find illicit substances in the course of routine traffic stops.
} 
have to county offsets. If police increase their seizures when counties cut their budgets, then our estimates may be capturing this reaction as well. To try to distinguish between budget offsetting and police "fund-raising" in anticipation of shortfalls, we exploit the timing of mayoral election cycles to see how the systematic increase in police spending experienced in election years affects the value of asset seizure activity. Counties are assigned the mayoral election year of the largest city in the jurisdiction and the analysis for this section is limited to 52 large U.S. cities. ${ }^{23}$

Table 4 looks at the relationship between the timing of mayoral elections and police budgets and arrests for our full sample and the sample of 5 states. Mayoral elections are associated with an increase in per capita county-level police spending of roughly two dollars in the full sample and four dollars in the state sample. One reason for the higher average spending response to mayoral elections in the smaller sample is that it is restricted to a higher share of counties that correspond uniquely to a city (e.g. Miami, New York, Philadelphia, San Francisco). In other words, the full sample may introduce more measurement error into the election-year indicators. To the extent that county spending includes spending from towns and cities that do not have directly elected mayors and/or are not on the same election cycle as the main city in that county, we are understating the increase in spending associated with mayoral elections. Nonetheless, these results strongly suggest that real per capita spending on police increases in election years. ${ }^{24}$ The results in columns (2) and (3) suggest that mayoral elections are only weakly related to a reduction in drug arrests relative to index crimes arrests (or total arrests).

Table 5 uses this variation to instrument for police budgets and to then examine whether police adjust their seizure behavior in response to exogenous changes in their budget. Column

\footnotetext{
${ }^{23}$ Levitt (1997) and McCrary (2002) consider 59 large cities. We cut the sample down slightly because some of the associated counties are not in our main analysis. These cities are: Arlington, TX; Austin, TX; Honolulu, HI; Mesa, AZ; New Orleans, LA; Saint Paul, MN; and Washington, D.C.

${ }^{24}$ We found no effect on spending in other budget categories - consistent with previous literature.
} 
(1) presents the OLS regression results from our two samples. The point estimates are negative, suggesting that increases in spending are associated with reductions in the value of seizures, but in neither case are they statistically distinguishable from zero. The main 2SLS regression results in columns (2) and (3), with the latter including state-specific time trends, are fairly precisely estimated and are significantly larger than the OLS coefficients. They suggest that a one dollar per capita exogenous increase in police spending leads to a roughly 6 cent decrease in per capita seizures. This reaction is interesting, but small in light of the offset estimates in Table 2 (which suggest an almost dollar for dollar reduction in police budgets). Indeed, if we assume that the estimated dollar reduction in police spending following a dollar increase in DOJ seizures captures county offsets and police behavior alone, then police fundraising can account for at most 6 percent of the relationship. In contrast, police fundraising may account for as much as 23 percent (6/26) of the estimated relationship between states seizures and police budgets. In both cases, however, these estimates suggest that, while the offset estimates may also capture a behavioral response on the part of police, this bias is rather small.

\section{Police Responses to Incentives}

We next explore the responses of police to the de jure and de facto incentives that they face. We include the statutory sharing rule to capture de jure incentives, but interact them with an indicator variable for states in which counties do the most offsetting of police seizures, as described in equation (5) above. Taken together with state statutory sharing rates, this offsetting measure allows us to estimate the response of police seizure activity to net or de facto financial incentives.

These results are shown in Table 6. As shown in columns (1) and (2), while police respond to the share of seizures they are entitled to keep by statute, they respond more when they 
are in states where localities actually allow them to keep the funds without an offsetting reduction in other allocations. In particular, a 10 percentage point increase in state sharing is associated with an increased value of state seizures of roughly 19 cents per capita plus an additional 9 cents per capita in states where there is relatively little offsetting of DOJ seizures. Police are also much more likely to use the state program relative to the DOJ program when they are allowed to keep more of the proceeds without offset, as shown in columns (3) and (4). (Note that this specification speaks to the mix of seizures, and thus abstracts from other factors that might be influencing the magnitude of seizures.)

If the de facto sharing of seizures influences the amount of seizing that police do, it must be influencing the number of arrests, composition of arrests (between drugs and other crimes), or character of drug arrests (bigger busts, more arrests for sales versus possession). Columns (5) through (12) explore these mechanisms. Comparing columns (5) and (6) suggests that while localities in states with higher statutory sharing make more drug arrests per capita, this effect holds only where budgetary reductions are not used to offset seizures. In other words, it is de facto rather than de jure sharing rules that are associated with higher drug arrest rates. This relationship between de facto as opposed to de jure sharing and drug arrest rates is true not only in an absolute sense but also as a proportion of index crime arrests (columns (9) and (10)). Finally, conditional on making a drug arrest, police in states that allow them to keep more of their seizures are also less likely to make the arrest for sales as opposed to possession. This finding is consistent with policies aimed at targeting money rather than drugs. For example, in the 1980s police in New York City were directed to impose roadblocks on the southbound lanes of I-95, where drug buyers could be found carrying cash, rather than northbound lanes, where sellers could be found carry drugs (Blumenson and Nielsen 1998). In short, these results are 
consistent with the idea that police respond to increased net incentives (statutory sharing minus budgetary offsets) by seizing more and that they do so by making more drug arrests per capita and focusing more on drug possession offenses.

\section{CONCLUSION}

Counties and police respond to incentives driven by seizures laws in a sophisticated way that depends both on the reaction of the other party and on the fiscal circumstances that affect their marginal utility of the funds. We find that local governments do indeed capture a significant fraction of the seizures that police make by reducing their other allocations to policing, undermining the statutory incentive created by state seizure laws. They are more likely to do so in times of fiscal distress. Police, in turn, respond to the real net incentives for seizures, once local offsets are taken into account, not simply the incentives set out in statute. When de facto policies allow police to keep the assets they seize, they seize more. Thus, a simple analysis of the effects of asset forfeiture laws, as they appear on the books, will provide a limited or even distorted view of the effects of these policies.

More generally, these findings have strong implications for the effectiveness of using financial incentives to solve agency problems in the provision of public goods in a federal system. The effectiveness of federal and state laws in influencing agents' behavior is limited by the ability of local governments to divert funds to other uses. Ignoring this yields a misleading picture of the responsiveness of local agents to incentives and the effectiveness of federal and state policies. Understanding the financial incentives faced by each agency and each level of government involved in the budget process is a crucial component of designing policies to affect the provision of public goods. 


\section{ApPendiX I: Data On Forfeitures Through State Programs}

\section{Arizona}

- Since at least 1994, the Arizona Attorney General could transfer all money and proceeds from forfeitures to the seizing agency. The forfeiture laws specify that money from drug seizures be used for law enforcement purposes or for highly targeted, anti-gang-related or anti-drug-related youth activities.

- We have obtained Arizona state-processed seizures and proceeds as well as disbursements for the DOJ to local agencies (reported by county) are available for fiscal years 1995-2001.

\section{California}

- Since 1994, California has divided the proceeds from seizures between the education (24 percent), the prosecuting agency (10 percent), a nonprofit for educating law enforcement and prosecutors on asset forfeiture (1 percent), and law enforcement ( 65 percent, although with restrictions that vary by county). There is some anecdotal evidence that these funds have been anticipated in state budgets, and that allocations to counties have been reduced accordingly.

- We have obtained California data on seizures by and disbursements to individual agencies for 1996 to 2001 and by county for 1995-2001 calendar years.

\section{Florida}

- Distribution method varies by seizing agency, but may not be spent on normal, law enforcement operating expenses. (For example, buying police cars would not be permissible, but helping a particular neighborhood impacted by illegal substances would be considered appropriate.) Agencies that received at least $\$ 15,000$ must expend at least 15 percent of the proceeds for drug treatment/education/prevention, crime prevention, safe neighborhoods, or school resource officer programs.

- We have obtained provided semi-annual reports on seizures and disbursements from Florida. The data is available electronically for 1996 to 2002, and in hard copy from 1992 to 1996.

\section{New York}

- Since 1990, roughly 30 percent of seizures in New York are returned to the claiming authority (DA), 40 percent to the claiming agent (usually the local police agency, but some DAs have their own police agents), and 30 percent to substance abuse fund (OASAS).

- We obtained New York data on seizures and disbursements from annual reports in hard copy with information at the agency and county level for 1992 to 2001 calendar years.

\section{Pennsylvania}

- District Attorneys and Attorneys General receive 100 percent of proceeds from forfeitures in Pennsylvania, but usually give it back to the seizing agency, with the provision that the money must be used for drug enforcement.

- We have obtained Pennsylvania data on state-processed seizures and proceeds for fiscal years 1994-2001. We have coded the data on cash seizures and proceeds from property sold. 


\section{REFERENCES}

Abt Associates (for National Assessment Program), Use of Forfeiture Sanction in Drug Cases.

Baicker, Katherine, The Budgetary Repercussions of Capital Convictions, NBER Working Paper 8382, 2001.

Baicker, Katherine, and Nora Gordon, The State Giveth and the State Taketh Away?: School Finance Equalizations and Net Redistribution, mimeo, 2004.

Benson, Bruce, David Rasmussen, and David Sollars, Police Bureaucracies, Their Incentives, and the War on Drugs, Public Choice, Vol. 83, 1995.

Benson, Bruce and David Rasmussen, Predatory Public Finance and the Origins of the War on Drugs The Independent Review, Vol. I, no. 2, Fall 1996.

Benson, Bruce and David Rasmussen, The Context of Drug Policy: An Economic Interpretation, Journal of Drug Issues, Vol 28, no. 3, 1998.

Blumenson, Eric, and Eva Nilsen, The Drug War's Hidden Economic Agenda, The Nation, March 9, 1998.

Blumenson, Eric, and Eva Nilsen, Policing for Profit, University of Chicago Law Review, Vol. 65, no. 35, 1998.

Blumenson, Eric, and Eva Nilsen, The Next Stage of Forfeiture Reform, Federal Sentencing Reporter, Vol. 14, no. $2,2001$.

Cassella, Stefan D. Forfeiture is Reasonable and it Works, Criminal Law and Procedure News, Vol. 1, no. 2, Spring 1997.

Di Eduardo, Chris. Bill Seeks to Modify Asset Forfeiture Laws, Las Vegas Review-Journal, April 22, 2001.

Dillon, Karen. Cash in Custody: A Special Report on Police and Drug Money Seizures, Kansas City Star, May 19, 2000 .

Ehlers, Scott, Policy Briefing: Asset Forfeiture, Drug Policy Foundation, 1999.

Gordon, Roger H. and John D. Wilson. Tax Structure and Government Behavior, NBER Working Paper 7244, 1999.

Guerra, Reconciling Federal Asset Forfeiture and Drug Offence Sentencing

Levitt, Steven, Using Electoral Cycles in Police Hiring to Estimate the Effect of Police on Crime, American Economic Review, Vol. 87, no. 3, June 1997.

Levy, Leonard, A License to Steal, University of North Carolina Press, Chapel Hill, 1996.

Mast, Brent, Bruce Benson, and David Rasmussen, Entrepreneurial Police and Drug Enforcement Policy, Public Choice, Vol. 104, 2000.

McCrary, Justin, Using Electoral Cycles in police Hiring to Estimate the Effect of Police on Crime: Comment, American Economic Review, Vol. 92, no. 4, 2002.

Miller, Mitchell and Lance Selva, Drug Enforcement's Double-Edged Sword: An Assessment of Asset Forfeiture Programs, Justice Quarterly, Vol. 11, no. 2, June 1994.

Rasmussen, David and Bruce Benson, The Economic Anatomy of a Drug War, Rowman and Littlefield Publishers, London, 1994. 
Short, Ernest H., Civil Forfeiture of Real Property and the Civil Asset Forfeiture Reform Act of 2000, Oklahoma Bar Journal, Vol. 73, no. 18, 2002.

Stellwagen, Lindesey D. and Karen A. Wylie, Strategies for Supplementing the Police Budget, Issues and Practices in Criminal Justice, National Institute of Justice, May 1985.

Stellwagen, Lindesey D., Use of Forfeiture Sanctions in Drug Cases, Research in Brief, National Institute of Justice, July 1985.

Worchol, Greg and Brian Johnson, Guilty Property: A Quantitative Analysis of Civil Asset Forfeiture, American Journal of Criminal Justice, Vol. 21, No. 1, 1996.

Worrall, Addicted To The Drug War: The Role Of Civil Asset Forfeiture As A Budgetary Necessity In Contemporary Law Enforcement, Journal of Criminal Justice, Vol. 29 (2001). 
Table 1: Summary Statistics

\begin{tabular}{lrrr}
\hline \hline & Mean & \multicolumn{1}{c}{ Std Dev } & N \\
\hline Panel A: Full Sample & & & \\
\hline Seizures through DOJ (\$real per capita) & $\$ 1.97$ & $\$ 2.94$ & 27576 \\
Share of City-Years in a Mayoral Election & 0.31 & 0.46 & 1040 \\
County Budgets (\$real per capita) & & & \\
$\quad$ Total Spending & $\$ 867.43$ & $\$ 1,000.59$ & 45536 \\
$\quad$ Allocations to Police & $\$ 45.41$ & $\$ 61.41$ & 45307
\end{tabular}

Arrests (per capita)

\begin{tabular}{lrrr} 
Total Arrests & 4873.6 & 2626.7 & 50081 \\
"Index" Crime Arrests & 916.1 & 529.1 & 50076 \\
Drug Arrests & 446.0 & 368.7 & 50285 \\
\hline 5-State Sample & & & \\
\hline through States (\$real per capita) & $\$ 1.14$ & $\$ 2.01$ & 1536 \\
through DOJ (\$real per capita) & $\$ 3.51$ & $\$ 4.65$ & 2385 \\
City-Years in a Mayoral Election & 0.27 & 0.45 & 395 \\
Budgets (\$real per capita) & & & \\
Total Spending & $\$ 1,336.46$ & $\$ 1,447.68$ & 4629 \\
Allocations to Police & $\$ 76.83$ & $\$ 91.43$ & 4542
\end{tabular}

Arrests (per capita)

Total Arrests

$4899.9 \quad 2616.3 \quad 4371$

$\begin{array}{llll}\text { "Index" Crime Arrests } & 948.9 & 528.8 & 4366\end{array}$

$\begin{array}{llll}\text { Drug Arrests } & 597.1 & 419.6 & 4371\end{array}$

Notes: County-year observations, weighted by population.

State program seizures are from PA, NY, CA, FL, and NY, various years

(spanning 1994-2001).

DOJ program seizures are reported by DOJ by judicial districts (allocated to counties based on population), 1990-1998.

County budget data from Bureau of the Census, 1990-2001.

Arrest data from Uniform Crime Reports, 1990-2001. 
Table 2: The Effect of Seizures on Police Budgets

Dependent Variable: Per Capita Police Budgets

\begin{tabular}{|c|c|c|c|c|c|c|c|c|}
\hline \multicolumn{9}{|c|}{ Panel A: DOJ Seizures 1991-1999 } \\
\hline Lagged DOJ Seizures & $\begin{array}{r}-1.55 \\
(.59)\end{array}$ & $\begin{array}{r}-0.95 \\
(.60)\end{array}$ & $\begin{array}{r}-1.31 \\
(.63)\end{array}$ & $\begin{array}{r}-1.06 \\
(.699)\end{array}$ & $\begin{array}{r}-0.39 \\
(.37)\end{array}$ & $\begin{array}{r}-0.01 \\
(.40)\end{array}$ & $\begin{array}{r}-0.10 \\
(.57)\end{array}$ & $\begin{array}{r}-0.01 \\
(.578)\end{array}$ \\
\hline County Deficit & & & & & $\begin{array}{l}0.005 \\
(.003)\end{array}$ & $\begin{array}{l}0.005 \\
(.002)\end{array}$ & $\begin{array}{l}0.002 \\
(.004)\end{array}$ & $\begin{array}{l}0.002 \\
(.003)\end{array}$ \\
\hline $\begin{array}{l}\text { Lagged DOJ Seizures* } \\
\text { County Deficit }\end{array}$ & & & & & $\begin{array}{r}-0.008 \\
(.001)\end{array}$ & $\begin{array}{r}-0.007 \\
(.002)\end{array}$ & $\begin{array}{r}-0.008 \\
(.001)\end{array}$ & $\begin{array}{r}-0.008 \\
(.001)\end{array}$ \\
\hline $\begin{array}{l}\mathrm{N} \\
\text { State-Specific Time Trends } \\
\text { Sample }\end{array}$ & $\begin{array}{r}17408 \\
\text { No } \\
\text { 48-state }\end{array}$ & $\begin{array}{r}17408 \\
\text { Yes } \\
\text { 48-state }\end{array}$ & $\begin{array}{r}1774 \\
\text { No } \\
\text { 5-state }\end{array}$ & $\begin{array}{r}1774 \\
\text { Yes } \\
\text { 5-state }\end{array}$ & $\begin{array}{r}15121 \\
\text { No } \\
\text { 48-state }\end{array}$ & $\begin{array}{r}15121 \\
\text { Yes } \\
\text { 48-state }\end{array}$ & $\begin{array}{r}1640 \\
\text { No } \\
\text { 5-state }\end{array}$ & $\begin{array}{r}1640 \\
\text { Yes } \\
\text { 5-state }\end{array}$ \\
\hline \multicolumn{9}{|c|}{ Panel B: State Seizures 1996-2001 } \\
\hline Lagged State Seizures & & & $\begin{array}{r}-0.26 \\
(.87)\end{array}$ & $\begin{array}{r}-0.42 \\
(.84)\end{array}$ & & & $\begin{array}{r}-0.27 \\
(.87)\end{array}$ & $\begin{array}{r}-0.50 \\
(.89)\end{array}$ \\
\hline County Deficit & & & & & & & $\begin{array}{r}-0.001 \\
(.007)\end{array}$ & $\begin{array}{l}0.001 \\
(.007)\end{array}$ \\
\hline $\begin{array}{l}\text { Lagged State Seizures* } \\
\text { County Deficit }\end{array}$ & & & & & & & $\begin{array}{r}-0.006 \\
(.002)\end{array}$ & $\begin{array}{l}-0.007 \\
(.003)\end{array}$ \\
\hline $\begin{array}{l}\mathrm{N} \\
\text { State-Specific Time Trends } \\
\text { Sample }\end{array}$ & & & $\begin{array}{r}951 \\
\text { No } \\
\text { 5-state } \\
\end{array}$ & $\begin{array}{r}951 \\
\text { Yes } \\
\text { 5-state } \\
\end{array}$ & & & $\begin{array}{r}846 \\
\text { No } \\
\text { 5-state }\end{array}$ & $\begin{array}{r}846 \\
\text { Yes } \\
\text { 5-state }\end{array}$ \\
\hline
\end{tabular}

Standard errors are clustered by state and given in parentheses.

All regressions include county and year fixed effects and are weighted by population.

County deficit is equal to spending minus revenue and is thus positive in times of fiscal stress.

Controls include total county spending, per capita index crime arrests, and county unemployment rates.

DOJ seizures are reported at the judicial district level, and have been allocated to counties within judicial districts based on population. 48 states are all but $\mathrm{HI}$ and AK; 5-state sample includes AZ, CA, FL, NY, and PA. 
Table 3: The Effect of Seizures on Other Budget Items

\begin{tabular}{|c|c|c|c|c|c|c|c|c|}
\hline \multicolumn{9}{|c|}{ Panel A: 48 State Sample, 1991-1999 } \\
\hline $\begin{array}{l}\text { Dependent Variable is } \\
\text { Real Per Capita }\end{array}$ & Police & $\begin{array}{l}\text { Corrections and } \\
\text { Judicial }\end{array}$ & Highways & $\begin{array}{c}\text { Public } \\
\text { Welfare }\end{array}$ & Police & $\begin{array}{l}\text { Corrections } \\
\text { and Judicial }\end{array}$ & Highways & $\begin{array}{c}\text { Public } \\
\text { Welfare }\end{array}$ \\
\hline Lagged DOJ Seizures & $\begin{array}{r}-1.547 \\
(0.567)\end{array}$ & $\begin{array}{r}0.973 \\
(0.139)\end{array}$ & $\begin{array}{r}-0.471 \\
(0.191)\end{array}$ & $\begin{array}{r}0.411 \\
(0.457)\end{array}$ & $\begin{array}{r}-0.394 \\
(0.361)\end{array}$ & $\begin{array}{r}0.726 \\
(0.148)\end{array}$ & $\begin{array}{r}-0.194 \\
(0.227)\end{array}$ & $\begin{array}{r}-0.839 \\
(0.527)\end{array}$ \\
\hline County Deficit & & & & & $\begin{array}{r}0.005 \\
(0.003)\end{array}$ & $\begin{array}{r}0.004 \\
(0.003)\end{array}$ & $\begin{array}{r}0.006 \\
(0.006)\end{array}$ & $\begin{array}{r}0.021 \\
(0.019)\end{array}$ \\
\hline $\begin{array}{l}\text { Lagged DOJ Seizures* } \\
\text { County Deficit }\end{array}$ & & & & & $\begin{array}{r}-0.008 \\
(0.001)\end{array}$ & $\begin{array}{r}0.001 \\
(0.001)\end{array}$ & $\begin{array}{r}0.001 \\
(0.001)\end{array}$ & $\begin{array}{r}0.011 \\
(0.003)\end{array}$ \\
\hline $\mathrm{N}$ & 17204 & 17291 & 15812 & 15084 & 14919 & 14975 & 13599 & 13305 \\
\hline \multicolumn{9}{|c|}{ Panel B: 5 State Sample, 1991-1999 } \\
\hline $\begin{array}{l}\text { Dependent Variable is } \\
\text { Real Per Capita }\end{array}$ & Police & $\begin{array}{l}\text { Corrections and } \\
\text { Judicial }\end{array}$ & Highways & $\begin{array}{c}\text { Public } \\
\text { Welfare }\end{array}$ & Police & $\begin{array}{l}\text { Corrections } \\
\text { and Judicial }\end{array}$ & Highways & $\begin{array}{c}\text { Public } \\
\text { Welfare }\end{array}$ \\
\hline Lagged DOJ Seizures & $\begin{array}{r}-1.297 \\
(0.556)\end{array}$ & $\begin{array}{r}0.840 \\
(0.272)\end{array}$ & $\begin{array}{r}-0.533 \\
(0.204)\end{array}$ & $\begin{array}{r}0.245 \\
(0.695)\end{array}$ & $\begin{array}{r}-0.106 \\
(0.498)\end{array}$ & $\begin{array}{r}0.582 \\
(0.199)\end{array}$ & $\begin{array}{r}-0.076 \\
(0.150)\end{array}$ & $\begin{array}{r}-0.928 \\
(0.768)\end{array}$ \\
\hline County Deficit & & & & & $\begin{array}{r}0.002 \\
(0.003)\end{array}$ & $\begin{array}{r}0.003 \\
(0.005)\end{array}$ & $\begin{array}{r}0.009 \\
(0.003)\end{array}$ & $\begin{array}{r}0.033 \\
(0.023)\end{array}$ \\
\hline $\begin{array}{l}\text { Lagged DOJ Seizures* } \\
\text { County Deficit }\end{array}$ & & & & & $\begin{array}{r}-0.008 \\
(0.001)\end{array}$ & $\begin{array}{r}0.001 \\
(0.000)\end{array}$ & $\begin{array}{r}0.000 \\
(0.000)\end{array}$ & $\begin{array}{r}0.008 \\
(0.005)\end{array}$ \\
\hline $\mathrm{N}$ & 1774 & 1776 & 1770 & 1761 & 1640 & 1642 & 1638 & 1633 \\
\hline
\end{tabular}

Standard errors are clustered by state and given in parentheses.

All regressions include county and year fixed effects and are weighted by population.

County deficit is equal to spending minus revenue and is thus positive in times of fiscal stress.

Controls include total county spending, per capita index crime arrests, and county unemployment rates.

DOJ seizures are reported at the judicial district level, and have been allocated to counties within judicial districts based on population. 48

states are all but $\mathrm{HI}$ and $\mathrm{AK}$; 5-state sample includes AZ, CA, FL, NY, and PA. 


\section{Table 4: Mayoral Election Cycles}

\begin{tabular}{|c|c|c|c|}
\hline \multirow{3}{*}{ Dependent Variable: } & \multicolumn{3}{|c|}{ "All" Cities } \\
\hline & \multirow[t]{2}{*}{ Police Budgets } & \multicolumn{2}{|c|}{ Arrests } \\
\hline & & Index Crimes & Drug / Index \\
\hline Mayoral election year indicator & $\begin{array}{r}2.02 \\
(0.93)\end{array}$ & $\begin{array}{r}-8.5 \\
(10.9)\end{array}$ & $\begin{array}{r}-0.003 \\
(.002)\end{array}$ \\
\hline State-Specific Time Trends & yes & yes & yes \\
\hline \multirow[t]{2}{*}{ Observations } & 699 & 699 & 682 \\
\hline & \multicolumn{3}{|c|}{ Cities in 5 States } \\
\hline \multirow[t]{2}{*}{ Dependent Variable: } & Police Budgets & \multicolumn{2}{|c|}{ Arrests } \\
\hline & & Index Crimes & Drug / Index \\
\hline Mayoral election year indicator & $\begin{array}{r}4.28 \\
(0.96)\end{array}$ & $\begin{array}{r}-9.2 \\
(11.2)\end{array}$ & $\begin{array}{r}-0.001 \\
(.002)\end{array}$ \\
\hline State-Specific Time Trends & yes & yes & yes \\
\hline Observations & 245 & 244 & 230 \\
\hline
\end{tabular}

Standard errors are clustered by state and given in parentheses.

All regressions include county and year fixed effects.

Controls include per capita spending on public welfare, reported index crimes per capita

(for budgets and seizures) and county employment to population ratio.

The "All" Cities sample includes 52 large US cities; the sub-sample 16 such cities. 
Table 5: Effect of Police Budgets on Seizures

\begin{tabular}{|c|c|c|c|}
\hline \multirow[t]{2}{*}{ Dependent Variable: } & \multicolumn{3}{|c|}{ Per Capita DOJ Program Seizures } \\
\hline & OLS & 2SLS & 2SLS \\
\hline & \multicolumn{3}{|c|}{ "All" Cities } \\
\hline Police Budgets & $\begin{array}{c}-0.009 \\
(0.010)\end{array}$ & $\begin{array}{c}-0.053 \\
(0.029)\end{array}$ & $\begin{array}{c}-0.06 \\
(0.026)\end{array}$ \\
\hline \multirow[t]{2}{*}{ Observations } & $\begin{array}{l}\text { No } \\
399\end{array}$ & $\begin{array}{l}\text { No } \\
399\end{array}$ & $\begin{array}{l}\text { Yes } \\
399\end{array}$ \\
\hline & \multicolumn{3}{|c|}{ Cities in 5 States } \\
\hline Police Budgets & $\begin{array}{c}-0.006 \\
(0.010)\end{array}$ & $\begin{array}{c}-0.059 \\
(0.022)\end{array}$ & $\begin{array}{c}-0.057 \\
(0.020)\end{array}$ \\
\hline State-Specific Time Trends & No & No & Yes \\
\hline Observations & 147 & 147 & 147 \\
\hline
\end{tabular}

Standard errors are clustered by state and given in parentheses.

All regressions include city and year fixed effects and are weighted by population.

Controls include per capita spending on public welfare, index crimes per capita and county employment to population ratio.

The timing of maryoral elections is the instrument for police budgets.

The "All" Cities sample includes 52 large US cities; the sub-sample 16 such cities. 
Table 6: Effect of Sharing on Policing

\begin{tabular}{|c|c|c|c|c|c|c|c|c|c|c|c|c|}
\hline & \multicolumn{4}{|c|}{ State Seizures } & \multicolumn{8}{|c|}{ Arrest Rates } \\
\hline & \multicolumn{2}{|c|}{ State Program } & \multicolumn{2}{|c|}{$\begin{array}{l}\text { State Program / } \\
\text { DOJ Program }\end{array}$} & \multicolumn{2}{|c|}{ Drugs } & \multicolumn{2}{|c|}{ Index Crimes } & \multicolumn{2}{|c|}{ Drugs / Index } & \multicolumn{2}{|c|}{$\begin{array}{l}\text { Drug Sales / Total } \\
\text { Drug }\end{array}$} \\
\hline $\begin{array}{l}\text { Statutory share state proceeds } \\
\text { agencies can keep }\end{array}$ & $\begin{array}{l}2.30 \\
(.96)\end{array}$ & $\begin{array}{l}1.88 \\
(.89)\end{array}$ & $\begin{array}{r}2.51 \\
(1.13)\end{array}$ & $\begin{array}{r}2.41 \\
(1.11)\end{array}$ & $\begin{array}{l}109.5 \\
(12.1)\end{array}$ & $\begin{array}{r}3.8 \\
(13.2)\end{array}$ & $\begin{array}{r}53.5 \\
(21.0)\end{array}$ & $\begin{array}{l}-127.6 \\
(24.0)\end{array}$ & $\begin{array}{l}0.018 \\
(.002)\end{array}$ & $\begin{array}{r}-0.004 \\
(.002)\end{array}$ & $\begin{array}{l}0.062 \\
(.009)\end{array}$ & $\begin{array}{l}0.155 \\
(.011)\end{array}$ \\
\hline $\begin{array}{l}\text { Statutory state share kept*Dummy for } \\
\text { states that do not offset much }\end{array}$ & & $\begin{array}{l}0.89 \\
(.23)\end{array}$ & & $\begin{array}{l}0.50 \\
(.28)\end{array}$ & & $\begin{array}{l}170.0 \\
(13.4)\end{array}$ & & $\begin{array}{l}271.0 \\
(21.3)\end{array}$ & & $\begin{array}{r}0.034 \\
(.002)\end{array}$ & & $\begin{array}{r}-0.144 \\
(.009)\end{array}$ \\
\hline $\mathrm{N}$ & 1106 & 1106 & 668 & 668 & 26637 & 26637 & 26637 & 26637 & 23991 & 23991 & 22886 & 22886 \\
\hline
\end{tabular}

Standard errors are clustered by state and given in parentheses.

All regressions include county fixed effects and are weighted by population.

Controls include grand total arrest rates (for seizures), total county spending and (un)employment rate.

States that do not offset much are defined as those in which county allocations to police are reduced less than the average in response to DOJ-procsessed

seizures. 